\title{
Research on the Influence of Farmers' Wage Income in Heilongjiang from National Agricultural Investment
}

\author{
Zhang Dehua \\ Institute of Finance \\ Harbin University of Commerce \\ Harbin, China, 150028 \\ e-mail: zdh19841027@163.com
}

\begin{abstract}
Farmers' wage income is increasingly growing in Heilongjiang, but the growth rate is not high. With the implementation of national food security strategy, Heilongjiang receives national agricultural investment continually. Whether it will hamper farmers' wage income growth or not has become a new problem. Through correlation analysis, multiple linear regression and path analysis, the paper using the relevant data from 1995 to 2013 analyzes the relationship between farmers' wage income in Heilongjiang and national agricultural inputs, analyzes its direct and indirect influences and ultimately comes to the conclusion that national investment has a positive impact on farmers' wage income.
\end{abstract}

Keywords- national agricultural investment; farmers; wage income; direct influence; indirect influence

\section{MODEL SELECTION}

\section{A. Multiple linear regressions}

The purpose of the study is to analyze influencing factors of farmers' income and gets its main reason. So the paper analyzes the selected data using multiple linear regression models and specific form of the model is as follows ${ }^{[1]}$ :

$$
Y=\mathrm{C}+\sum_{i=1}^{n} \beta_{i} X_{i}+\varepsilon
$$

$\mathrm{Y}$ represents the farmers' income, $\mathrm{C}$ is a constant term, $\beta \mathrm{i}$ is regression coefficients of corresponding variable, $\mathrm{Xi}$ is the corresponding variable, $\mathcal{E}$ is a random disturbance, the range of $\mathrm{n}$ is between 1 and 21 .

\section{B. Path analysis}

In order to analyze the direct and indirect influence, this part draws on path analysis of Han Jie and the specific form is as follows ${ }^{[2]}$ :

$$
\left\{\begin{array}{l}
Z_{11} K_{1}+Z_{12} K_{2}+\cdots+Z_{1 n} K_{n}=Z_{1 Y} \\
Z_{21} K_{1}+Z_{22} K_{2}+\cdots+Z_{2 n} K_{n}=Z_{1 Y} \\
\vdots \\
Z_{n 1} K_{1}+Z_{n 2} K_{2}+\cdots+Z_{n n} K_{n}=Z_{n Y}
\end{array}\right.
$$

It can also be expressed as $Z_{Y}=Z K, Z_{Y}$ represents simple correlation coefficient matrix between $n$ indicators and dependent variable $\mathrm{Y}$, the matrix is $\mathrm{n} \times 1$ order matrix. $Z$ represents simple correlation coefficient matrix which is simple correlation coefficient between each indicator, the matrix is the $\mathrm{n} \times \mathrm{n}$ order matrix. $K$ represents direct path coefficients matrix between each indicator and $Y$, the matrix is $\mathrm{n} \times 1$ order matrix. $Z_{i j}$ represents correlation coefficient between $\mathrm{i}$ factor and $\mathrm{j}$ factor, $K_{j}$ represents direct path coefficient between $\mathrm{j}$ variable and dependent variable $\mathrm{Y}, Z_{i Y}$ represents simple correlation coefficient between $\mathrm{i}$ factor and dependent variable $\mathrm{Y}$.

\section{The simple correlation coefficient}

This part uses simple correlation coefficient which belongs to Pearson's simple correlation coefficient and draws on the analysis method of Zhang Hongbing, the specific formula is as follows ${ }^{[3]}$ :

$$
r=\frac{\sum_{i=1}^{n}\left(x_{i}-\bar{x}\right)\left(y_{i}-\bar{y}\right)}{\sqrt{\sum_{i=1}^{n}\left(x_{i}-\bar{x}\right)^{2}\left(y_{i}-\bar{y}\right)^{2}}}
$$

\section{MODEL INDICATOR SELECTION AND DIRECTION FORECAST}

\section{A. Game model selection}

Through combing the relevant literature, the paper gets to the conclusion that the main factors of influencing farmers' wage income in Heilongjiang are labor factor, labor transfer factors, national investment factor, mechanization factor, price factor and urbanization factor and the specific indicators are as follows: $\mathrm{X} 1$ is the proportion of junior higher education on average hundred labors, $\mathrm{X} 2$ is the number of rural labor force, $\mathrm{X} 3$ is the proportion of primary industry of rural labors, $\mathrm{X} 4$ is the national investment in agriculture, $\mathrm{X} 5$ is the average machinery gross power, $\mathrm{X} 6$ is $\mathrm{CPI}, \mathrm{X} 7$ is the proportion of urban population ${ }^{[4-7]}$. The direction forecast of influencing wage income from each factor is as follows: 
TABLE I. ASSUMING DIRECTION OF MODEL VARIABLES

\begin{tabular}{cc}
\hline variables & $\begin{array}{c}\text { assuming } \\
\text { direction }\end{array}$ \\
\hline $\begin{array}{c}\text { proportion of junior higher education } \\
\text { on average hundred labors }\left(\mathrm{X}_{1}\right)\end{array}$ & + \\
number of rural labor force $\left(\mathrm{X}_{2}\right)$ & - \\
proportion of primary industry of rural \\
labors $\left(\mathrm{X}_{3}\right)$
\end{tabular}

III. MODEL DATA SELECTION AND RESULT ANALYSIS

The paper chooses influencing factors of per capita net income in Heilongjiang from 1993 to 2010, including X1 the proportion of junior higher education on average hundred labors, X2 the number of rural labor force, X3 the proportion of primary industry of rural labors, $\mathrm{X} 4$ the national investment in agriculture, X5 the average machinery gross power, X7 the proportion of urban population and X6 CPI from 1993 to 2010. Using SPSS, the paper analyzes relevant data through correlation analysis, multiple linear regression and path analysis and arrives at the following conclusions:

TABLE II. CORRELATIONS

\begin{tabular}{|c|c|c|c|c|c|c|c|}
\hline & $\begin{array}{l}\text { Junior } \\
\text { higher } \\
\text { educa } \\
\text { tion }\end{array}$ & $\begin{array}{l}\text { num } \\
\text { ber } \\
\text { of } \\
\text { rural } \\
\text { labor } \\
\text { force }\end{array}$ & $\begin{array}{l}\text { prop } \\
\text { ortio } \\
\mathrm{n} \text { of } \\
\text { prim } \\
\text { ary } \\
\text { indus } \\
\text { try of } \\
\text { rural } \\
\text { labor } \\
\mathrm{s}\end{array}$ & $\begin{array}{c}\text { natio } \\
\text { nal } \\
\text { inves } \\
\text { tmen } \\
\mathrm{t} \text { in } \\
\text { agric } \\
\text { ultur } \\
\mathrm{e}\end{array}$ & $\begin{array}{c}\text { avera } \\
\text { ge } \\
\text { mach } \\
\text { inery } \\
\text { gross } \\
\text { powe } \\
\text { r }\end{array}$ & CPI & $\begin{array}{c}\text { prop } \\
\text { ortio } \\
n \text { of } \\
\text { urba } \\
n \\
\text { popu } \\
\text { latio } \\
n\end{array}$ \\
\hline \multirow[t]{3}{*}{ wage } & $\begin{array}{l}.876 \\
(* *)\end{array}$ & $\begin{array}{l}.706 \\
(* *)\end{array}$ & $\begin{array}{c}-.919 \\
(* *)\end{array}$ & $\begin{array}{l}.984 \\
(* *)\end{array}$ & $\begin{array}{l}.968 \\
(* *)\end{array}$ & -.355 & $\begin{array}{l}.727 \\
(* *)\end{array}$ \\
\hline & .000 & .001 & .000 & .000 & .000 & .148 & .001 \\
\hline & 18 & 18 & 18 & 18 & 18 & 18 & 18 \\
\hline
\end{tabular}

** Correlation is significant at the 0.01 level (2-tailed).

From the result, we can see that farmers' wage income in Heilongjiang has a positive correlation with $\mathrm{X} 1$ the proportion of junior higher education on average hundred labors, X2 the number of rural labor force, X4 the national investment in agriculture, $\mathrm{X} 5$ the average machinery gross power and $\mathrm{X} 7$ the proportion of urban population. It has a negative correlation with $\mathrm{X} 3$ the proportion of primary industry of rural labors and X6 CPI, but the correlation with X6 CPI is not significant. Among them, direction forecast of farmers' income is opposite with X2 the number of rural labor force and X6 CPI.
As we can see from the regression analysis results, two variable indicators are kept among seven indicators, which are $\mathrm{X} 4$ the national investment in agriculture and X1 the proportion of junior higher education on average hundred labors. X4 the national investment in agriculture enters the model first and its determination coefficient is 0.967 which indicates that X4 plays a significant role in influencing farmers' wage income in Heilongjiang and X4 the national investment in agriculture can explain the changes in wage income most among seven indicators. The second one is $\mathrm{X} 1$ the proportion of junior higher education on average hundred labors and its determination coefficient is 0.992 which increases by 0.25 .

TABLE III. VARIABLES ENTERED/REMOVED (A)

\begin{tabular}{|c|c|c|c|c|c|}
\hline Model & \multicolumn{3}{|c|}{ Variables Entered } & \multicolumn{2}{|c|}{ ariables Removed } \\
\hline 1 & \multicolumn{3}{|c|}{$\begin{array}{l}\text { national investment } \\
\text { in agriculture }\end{array}$} & \\
\hline 2 & \multicolumn{3}{|c|}{$\begin{array}{l}\text { proportion of junior } \\
\text { higher education on } \\
\text { average hundred } \\
\text { labors }\end{array}$} & · & \\
\hline \multicolumn{6}{|c|}{$\begin{array}{r}\text { a Dependent Variable: wage income } \\
\text { TABLE IV. MODEL SUMMARIES }\end{array}$} \\
\hline Model & $\mathrm{R}$ & uare & $\begin{array}{l}\text { Adjusted } \\
\text { R Square }\end{array}$ & $\begin{array}{l}\text { Std } \\
\text { the }\end{array}$ & $\begin{array}{l}\text { Error of } \\
\text { Estimate }\end{array}$ \\
\hline 1 & $984(\mathrm{a})$ & 67 & .965 & & 84869 \\
\hline \multirow[t]{3}{*}{2} & $996(b)$ & 92 & .991 & & 50022 \\
\hline & \multicolumn{5}{|c|}{ TABLE V. ANOVA(C) } \\
\hline & $\begin{array}{l}\text { Sum of } \\
\text { Squares }\end{array}$ & df & $\begin{array}{l}\text { Mean } \\
\text { Square }\end{array}$ & $\mathrm{F}$ & Sig. \\
\hline Regression & $\begin{array}{c}1926918 \\
.669\end{array}$ & 2 & $\begin{array}{l}96345 \\
9.334\end{array}$ & $\begin{array}{c}912.13 \\
8\end{array}$ & $.000(\mathrm{~b})$ \\
\hline Residual & $\begin{array}{c}15843.9 \\
69\end{array}$ & 15 & $\begin{array}{c}1056.2 \\
65\end{array}$ & & \\
\hline Total & $\begin{array}{c}1942762 \\
.638\end{array}$ & 17 & & & \\
\hline
\end{tabular}

Through regression analysis, we can see that $\mathrm{R} 2$ is 0.992 as the final model and R2 is 0.991 after adjustment, indicating that the fitting effect of model is great. $\mathrm{F}=$ 912.138 and sig. $=0.000<0.05$, which indicates that the model has passed $\mathrm{F}$ test and rejects the null hypothesis. The main factors of influencing farmers' wage income in Heilongjiang are $\mathrm{X} 4$ the national investment in agriculture and $\mathrm{X} 1$ the proportion of junior higher education on average hundred labors. They pass $t$ test at $5 \%$ significance level and their sig. value is 0.000 and 0.000 respectively which is less than $5 \%$. Their coefficients are 0.108 and 11.891 respectively. Finally, we get the decision equation of per capita wage income in Heilongjiang:

$Y=-609.602+11.891 X_{1}+0.108 X_{4}+\varepsilon$

Through the equation, we can see when $\mathrm{X} 4$ the national investment in agriculture increases a unit (100 million yuan) and farmers' wage income will increase 0.108 yuan. When X1 the proportion of junior higher education on 
average hundred labors increases a unit (a percentage point) and wage income will increase 11.891 yuan.

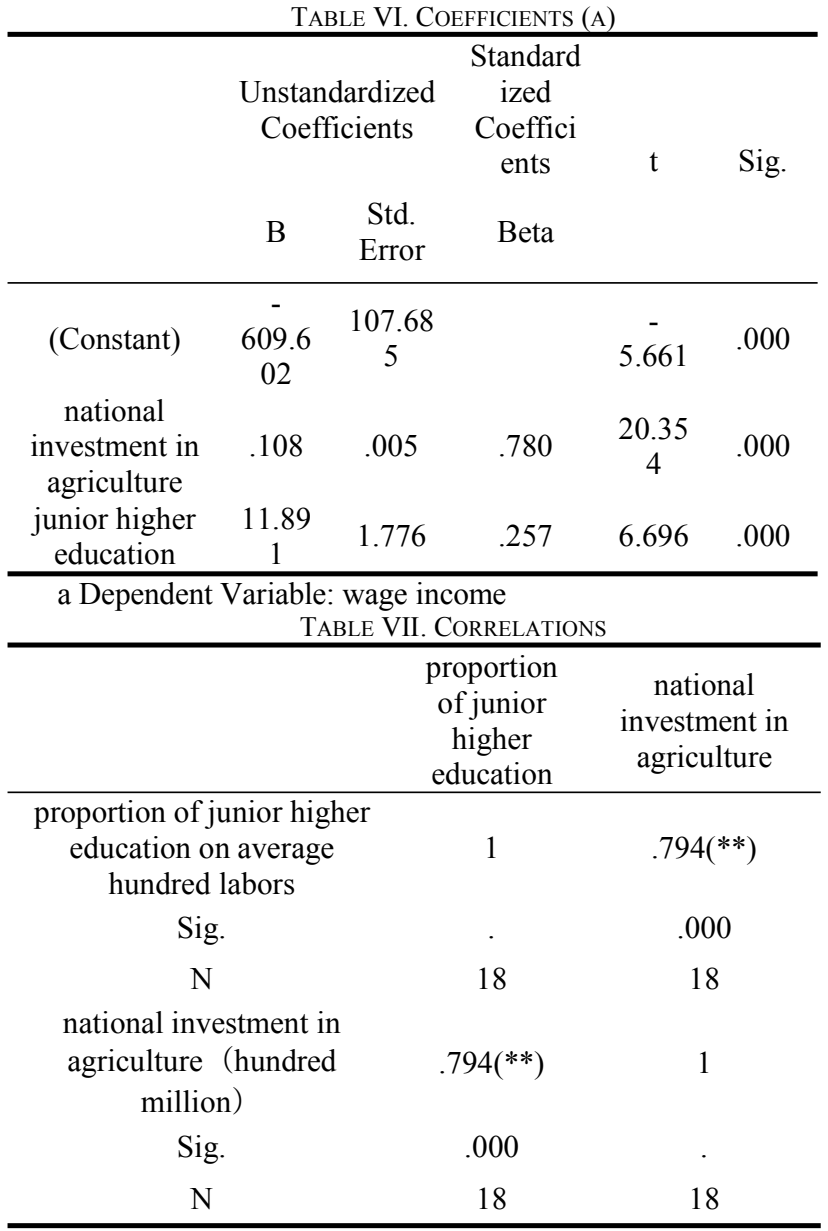

** Correlation is significant at the 0.01 level (2-tailed). TABLE VIII. PATH COEFFICIENT OF EACH INDICATOR

\begin{tabular}{l} 
indicators $\begin{array}{c}\text { direct } \\
\text { path } \\
\text { coeff } \\
\text { icient }\end{array} \begin{array}{c}\text { national } \\
\text { investment in } \\
\text { agriculture }\end{array} \begin{array}{c}\text { indirect path coefficient } \\
\text { proportion of } \\
\text { junior higher } \\
\text { education on } \\
\text { average } \\
\text { hundred labors }\end{array}$ \\
\hline $\begin{array}{c}\text { national } \\
\text { investment in } \\
\text { agriculture } \\
\text { proportion of } \\
\text { junior higher } \\
\text { education on } \\
\text { hundred labors }\end{array}$ \\
$\begin{array}{c}\text { Through path analysis, we can see that direct path } \\
\text { coefficient of X4 the national investment in agriculture is }\end{array}$ \\
$\begin{array}{l}0.780 \text { and indirect path coefficient of X1 the proportion of } \\
\text { junior higher education on average hundred labors is } 0.204 .\end{array}$ \\
Direct path coefficient of X1 the proportion of junior \\
higher education on average hundred labors is 0.257 and \\
direct path coefficient of X4 the national investment in \\
agriculture is 0.619 .
\end{tabular}

\section{CONCLUSIONS}

(1) National investment in agriculture is the investment factor $^{[8]}$. It is also an important indicator to measure investment factor which has a significant impact on farmers' wage income in Heilongjiang. It improves wage income directly and mostly concentrates in infrastructure construction. Heilongjiang, as the demonstration of agricultural modernization, is actively building a modern large-scale agriculture. National investment in infrastructure construction provides job opportunities directly and farmers staying at home can participate in agricultural infrastructure construction. Therefore, national investment in agriculture will contribute directly the growth of farmers' wage income ${ }^{[9]}$.

(2) The proportion of junior higher education on average hundred labors is labor quality factor ${ }^{[10]}$. It is the main indicator of measuring labor education quality. Its improvement enhances directly farmers' overall cultural quality. With the improvement of cultural quality, employment chances of rural labor forces can be increased; meanwhile, it can widen employment scope of labors; at last, it improves farmers' wage income in Heilongjiang.

\section{ACKNOWLEDGMENT}

The paper is funded by the following items. $\mathrm{PhD}$ Research Project Started of Harbin University of Commerce (14rw10). This paper is the phase progress of Philosophy and Social Science Project of Heilongjiang Province "Policy Combination and Supporting Measures of Rural Land Transfer ( item number 14B115) ". This paper is supported by Science Research Foundation of Northeast Agricultural University (item number 2012RCB77). This paper is the phase progress of Philosophy and Social Science Project of Ministry of Education "Research on the Mechanism Innovation of Rural Land Transfer and Its Efficiency \& Income Distribution (item number 14YJC790125)"

\section{REFERENCES}

[1] Stein Holden, Bekele Shiferaw and John Pender. Non-farm income, household welfare, and sustainable land management in a lessfavored area in the Ethiopian highlands [J]. Food Policy, 2004, (29):369-392.

[2] Chul-Woo Kwon, Peter Orazem, Daniel Otto. Off-farm labor supply responses to permanent and transitory farm income [J]. Agricultural Economics \& Resource Management, 2006, Vol.34 (1):59-67.

[3] Zhang Dehua, Zhou Huiqiu and Lou Sha. The problems and the countermeasures in food production in Heilongjiang [J]. Research of Agricultural Modernization. 2012(4):411-414.

[4] Lou Sha, Liu Huiping, Zhang Dehua. Comparative study on grain production and farmers' income coordination in Heilongjiang [J] Research of Agricultural Modernization. 2013, Vol.34 (6):654-658.

[5] Patton M. P, Kostov, S, McErlean, and J Moss. Assessing The Influence of Direct Payments On The Rental Value Of Agricultural Land [J]. Food Policy. 2008, Vol. 33(5): 397-405.

[6] Zhou Qiren. Property and Institutional Change [M]. Beijing University Press, 2004. 
[7] Zhang Dehua. Study on influential factors and countermeasures of farmers' income in Heilongjiang [M]. Harbin: Northeast Agricultural University, 2013.

[8] Cao Yukun, Chen Jiancheng, Chen Lirong. Game analysis on subject behaviors and policies in state-owned forest tenure reform in Yichun [J]. Issues in Agricultural Economy, 2010(5):89-95.
[9] Wang Chengzong, An empirical analysis of factors affecting farmers' income in Henan [J] Chinese Agricultural Science Bulletin, 2012, 28 (20): 226 - 229.

[10] Wang Peigang. Analysis on game path benefit subjects in current land expropriation [J]. Issues in Agricultural Economy, 2007(10):34-40. 